\title{
FACTORS DETERMINING THE QUALITY MANAGEMENT OF HIGHER EDUCATION: A CASE STUDY AT A BUSINESS SCHOOL IN INDONESIA
}

\author{
Eliot Simangunsong \\ Universitas Prasetiya Mulya, Indonesia \\ e-mail: elliot@pmbs.ac.id
}

\begin{abstract}
Despite the facts that higher education institutions are the source of quality concept and theory, they have been lagging behind manufacturing or service businesses in embracing and carrying out proper quality management. Managing quality in higher education is a difficult task due to several factors such as different perspectives between stakeholders and traditional characteristics of institutions. On the other hand, accreditation, for example by the Indonesian Bureau of Higher Education Accreditation, and international accreditation bodies, such as AACSB, EQUIS, is perceived as a tool to demonstrate a certain quality threshold. However, many studies argue that periodic quality assessments using recognized accreditation bodies do not touch inherent quality issues in education, and that they are generally used as an exercise of quality control. The objective of this study is to look beyond quality assessments using these recognized accreditation bodies and examine dimensions of quality from university's stakeholder's point of view, especially the stakeholder that represents the demand side. Factor analysis is conducted, and the number of factors proposed by the results are identified. There are seven quality dimensions that have impacts on the quality management system in higher education. Three dimensions are new findings, i.e., the importance of providing health and insurance, the importance of good ambiance of campus environment, and stakeholder's explicit ability to demonstrate quality in higher education.
\end{abstract}

Keywords: management, quality, higher education, factor analysis

\section{FAKTOR-FAKTOR YANG MENENTUKAN KUALITAS MANAJEMEN DI PENDIDIKAN TINGGI: KASUS DI SATU SEKOLAH BISNIS DI INDONESIA}

\begin{abstract}
Abstrak: Meskipun institusi pendidikan tinggi adalah sumber dari konsep dan teori kualitas, industri manufaktur dan bisnis jasa lainnya telah lebih dahulu melaksanakan konsep manajemen kualitas yang tepat. Mengelola kualitas dalam pendidikan tinggi adalah tugas yang sulit karena berbagai faktor seperti perspektif yang berbeda antara pemangku kepentingan dan karakteristik tradisional institusi yang unik. Di sisi lain, akreditasi, misalnya oleh Biro Akreditasi Nasional-Perguruan Tinggi di Indonesia, dan lembaga akreditasi internasional, seperti AACSB, EQUIS, digunakan sebagai alat untuk menunjukkan kualitas tertentu suatu institusi pendidikan tinggi. Hanya saja, banyak penelitian berpendapat bahwa penilaian kualitas secara periodik menggunakan badan-badan akreditasi tidak menyentuh masalah kualitas yang melekat dalam pendidikan, dan bahwa proses akreditasi umumnya digunakan untuk kontrol kualitas. Tujuan dari penelitian ini adalah untuk investigasi kualitas pendidikan tinggi yang melampaui akreditasi dan menganalisa dimensi kualitas dari sudut pandang stakeholder universitas, terutama pemangku kepentingan yang mewakili sisi permintaan. Analisis faktor telah dilakukan, dan jumlah faktor hasil analisis telah diidentifikasi. Ada tujuh dimensi kualitas yang berdampak pada sistem manajemen mutu di pendidikan tinggi dan diantaranya tiga dimensi kualitas adalah temuan baru, yaitu, pentingnya menyediakan kesehatan dan asuransi, pentingnya suasana lingkungan kampus yang baik, dan kemampuan eksplisit pemangku kepentingan untuk menunjukkan kualitas dalam pendidikan tinggi.
\end{abstract}

Kata Kunci: manajemen, kualitas, pendidikan tinggi, analisis faktor

\section{INTRODUCTION}

Application of quality management is well known in manufacturing or service industries (Grant, Mergen, \& Widrick, 2004; Lagrosen, Seyyed Hashemi, \& Leitner, 2004). Early quality management and improvement techniques is directed to manufacturing companies, followed by service companies and nonprofit organizations (Sirvanci, 2004). A study by Istileulova \& Peljhan (2013) identifies quality as the top priority of 
knowledge among companies that has moved from the literature of manufacturing strategy to the service arena. Quality Management has developed to a degree where it is viewed as a foundation for competition, a corporate prominence carried out to all business function and employees (Hellsten \& Klefsjö, 2000).

Higher education institution is the center of learning and creating new knowledge through their function, but unfortunately lagging behind other organizations, such as manufacturing industry, in embracing and implementing proper quality management. Sirvanci (2004) stated that this slow pace in the adoption of quality management seems to be due to the organizational structure and is an inherent tradition in higher education institutions. Becket (2008) added that higher education has been lagging behind manufacturing or service businesses in applying quality management because of various factors. Managing quality in higher education has proved to be a difficult task (Becket, 2008; Mohammed, Bin Taib, \& Nadarajan, 2016). University stakeholders have different perspective about quality; products in higher educational institutions are also complicated in nature.

On the other development, Quality Management System (QMS) on higher education institution is very important to respond to the increasingly competitive markets that drain the universities' financial resources and ability to act like commercial enterprises (Williams, 1993). Competition between higher education institutions are deemed as normal and generally accepted (Van Vught \&Westerheijden, 1994). Globalization also brings new opportunities for universities to expand to other countries. This trend of education globalization also plays an important role to the increased attention to the quality management in various higher education systems (Van Vught \& Westerheijden, 1994).

Grant et. al. (2004) found that universities around the world have started implementing seriously quality management systems to improve teaching, student satisfaction, curriculum, employer and university operations. A recent study by Pires (2015) identifies the underlying factors, i.e., growing financial pressures, quality enhancement pressures, price reduction, and rapid increase in the number of students. Public and private universities have to compete in the education market likes commercial enterprises
(Ardi, Hidayatno,\& Zagloel, 2012; Tari \& Dick, 2016). Continually improving quality is an essential element for the sustainability of higher educational institutions(Teeroovengadum, Kamalanabhan, \& Seebaluck, 2016).

Due to the rapid growth of the student body and the accompanying increase of the number of fields of study, departments, and even the whole new institutions, have initiated questions about the amount and direction of public expenditure for higher education. The limit of public expenditure and budget cuts has led to an increased attention to the quality of processes and accountability. Becket (2008) stated that the increasing number and diversity of students causes increased need of flexibility in education delivery.

Nigsch \& Schenker-Wicki (2013) argue that identification of quality factors from the stakeholders' perspective is important because the impact of quality improvement in higher education cannot be separated from the effect of relevant factors. Stakeholders in higher education consist of students and wider society, which represent the demand side, and higher education institution that represents the supply side (Martensson \& Richtner, 2015).

Besides the challenges discussed above, the Indonesian government (Kementerian Ristek dan Pendidikan Tinggi/Ministry of Research, Technology and Higher Education) brings further pressure to local institutions by publishing many new regulations to control quality of higher education, especially in the years 2013 to 2015 . It is difficult to increase the number of students of a particular university without a noticeable decrease in the education quality.

Currently, higher education institutions, especially business schools, have become a sector of business in their own right, internationalized, highly competitive and a global enterprise (Barton \& Yazdani, 2013). Quality dimensions can be used as a measurement to determine and improve the quality of programs and schools, and thus it becomes an endless concern for business schools. For example, accreditation is perceived as a tool in facilitating service quality in higher education institutions (Istileulova \& Peljhan, 2013). Accreditation has been used as a high quality measurement and a way to be listed in the high-ranking global institutions (Barton \& Yazdani, 2013; Nigsch \& Schenker-Wicki, 
2013). This method has been applied by European business schools as a response to its competitive pressures by increasing their quality metrics, through recognized, global accreditation bodies, such as European Foundation for Management Development Quality Improvement (EQUIS), Association to Advance Collegiate Schools of Business (AACSB), and Association of MBAs (AMBA). Here, Total Quality Management (TQM)and continuousimprovementtechnologies are being promoted within the business schools (Istileulova \& Peljhan, 2013).

However, Srikanthan \& Dalrymple (2003) argue that the periodic quality evaluations using recognized accreditation bodies (EQUIS, AACSB, AMBA) do not reflect the core issues of education; but they are generally used as an exercise of quality control. Nigsch \& SchenkerWicki (2013) also found that accreditation is still a controversial issue in higher education in terms of its benefits against risks of increased bureaucratization and control. They argue that despite accreditation effects on research performance, the real quality management practice is not necessary linked with ranking positions. Another recent study by Martensson \& Richtner (2015) found that student were less enthusiastic with some of the criteria used in rankings such as the over-emphasis of research. International accreditation also tends to favor big and rich business schools (Nigsch \& SchenkerWicki, 2013).

The objective of this study is to look beyond quality assessments using the standards endorsed by the recognized accreditation bodies (EQUIS, AACSB, AMBA) and examine dimensions to quality from university's stakeholders' point of view, especially the stakeholder that represents the demand side. Tari \& Dick (2016) suggest that good understanding of quality management dimensions can have a positive effect on university teaching and research performance. In this context, Becket (2008) found that limited research has been done in this area of field specifically on quality management in higher education. The result of this study will help higher education institutions to build up a working quality management system that goes beyond quality standards; which is usually used for accreditation purposes.

Identifying dimensions of quality from stakeholders' perspective is important because, as Nigsch \& Schenker-Wicki (2013) identified in their study, impacts of quality improvement in higher education cannot be separated from the effect of relevant factors to the stakeholders. Critical evaluation of the quality factors in higher education is still much needed in many countries, including Indonesia, because recent review conducted by Tari \& Dick (2016) shows significant differences between countries such as UK, USA, Australia and the rest of the world in terms of research in quality in higher education.

Many studies have proposed dimensions of quality in higher education. Grant et. al. (2004) reviewed 18 articles on quality management in higher education and identify three major dimensions of quality, i.e., Quality-of-Design, Quality-of-Conformance, and Quality-ofPerformance. Tari \& Dick (2016) did another literature review of 202 journals in business and education journals on quality management in higher education institutions. They identified six major dimensions of quality management, i.e., people management, information and analysis, process management, stakeholder focus, planning, and leadership. Each of the dimension consists of several sub-dimensions. Martensson \& Richtner (2015) use university students as the unit of analysis and are able to identify 24 factors that students perceive as important in higher education. They also rank the factors and list top ten variables as the most important. Psomas \& Antony (2017) conducted empirical research in Greek higher education and proposed nine fundamental elements i.e., leadership and top management commitment, strategic quality planning, teaching staff and employee management and involvement, supplier management, student focus, process management, continuous improvement, information and analysis and knowledge and education. Sofiyabadi \& Firoozabadi (2017) use quality dimensions of the Academic Quality Improvement Program (AQIP) and rank the importance for each dimension. There are nine dimensions which Sofiyabadi \& Firoozabadi (2017) found that understanding students' and other stakeholders' needs, planning for continuous improvement, helping students learn are the most important dimensions to develop and maturate TQM in higher education. The Ministry of Research and Higher Education of the Republic of Indonesia has also published 
quality indicators for accreditation purposes. Through the National Accreditation Board for Higher Education (BAN-PT), the Ministry of Research and Higher Education of the Republic of Indonesia regularly ranks higher institutions according to the specific quality indicators. There are 100 quality criteria grouped into seven components.

Until now, there is still no agreement on the best method to measure and manage quality in higher education. Because of this issue, many different methods have been carried out (Becket, 2008). There is a variety of output in the education system, be it tangible, intangible or value-added through, for example, examination results, employment, earnings and satisfaction. Becket (2008) has proved that managing quality in higher education is a demanding task. The reasons being that 'quality' can be defined differently depending on the point of view and the complex nature of educational products.

There are different points of view among stakeholders about the duty of a high quality system in higher education (Srikanthan \& Dalrymple, 2003). First, the financial backing organizations or the funding authorities are looking for satisfying returns on investment, thus creating education quality as 'value for money'. Secondly, students as the users of products appreciate quality of education as an advantage in career prospects after graduation. This is the purported role of league tables compiled by the private bodies from the quality audit and other performance data. Third, for the employers of graduates, quality of education is cherished by guaranteeing how the graduates could comparatively manage the job complexities to secure competitive advantage of the employed companies (Sirvanci, 2004). And lastly, it is the top management's leadership. There is a huge difference between CEOs of business organizations and presidents and chancellors of higher education institutions. Top management in higher education institutions prefer to share governance with faculty and deans, instead of hiring and firing staffs and allocating resources by means of ultimate authority.

Higher education institutions that have been established for a very long time, e.g., several centuries, usually have typical traditions.
They tend to refuse cultural and organizational transformation. For example, many faculty staff dislike the metaphor seeing the students as the customers of faculty in the classroom, as it is too commercial. There are controversies in treating student s' role as customers. Students are regarded as the output, and the employers are the customers of the higher education institutions. Another issue is how to control process and people. Traditionally, quality management is intended to monitor and control work process, and not as an instrument to increase managerial control over the faculty members (Pires, 2015).

Tari \& Dick (2016) argue that additional research is still needed to identify dimensions of quality management in higher education and to clarify how the management of higher education implements this in practice. Such research is not available in the Indonesian context. The available research mostly deals with the implementation of quality management in higher education.

\section{METHOD}

The method addressing the research objective is quantitative research that uses a set of survey questionnaires. Units of analysis are active undergraduate students of a particular business school in Jakarta, Indonesia.

Using only one unit of analysis in a study have a weakness in the result. The result of the study cannot be used generally, because the unit of analysis is only in one scope or object. Future work may include samples from a greater geographic area or be expanded to a multi-unit of analysis.

It is to be noted that many academic studies in this field used one unit of analysis. For example, recent study by Kardoyo \& Nurkhin (2016) analyses student satisfaction of Prodi Magister Pendidikan Ekonomi Universitas Negeri Semarang; another study by by Barton\& Yazdani (2013), about managing for the future in higher education is applied in a UK Business School, another research by Nitecki\& Hernon (2000) focused on Yale University's Library, and the research by Ardy et al, (2012) about investigating relationships among quality dimensions in higher education.

The advantage of using a single unit of analysis is that the researcher can control the quality of the data filled by the respondents, because it is monitored by the researcher and the 
institution (university) as well. It is also possible to get the higher number of good respondents by using this method.Using single unit of analysis is less time consuming and less expensive than multiple-case-study.

More research using quantitative approach is suggested in the study of Tari \& Dick (2016). They found that qualitative method was common in the field of quality management in higher education. Education journals publish more theoretical studies because this topic is a new field of research. However, there is a general trend of shifting from theoretical research to empirical research. Quantitative methods are needed to test and extend the theory further. Psomas \& Antony (2017) add that further empirical research is needed to gather data to continue the investigation of quality management in education.

This study consists of several phases. The first phase defines the research area and identifies research opportunities relevant to academicians and practitioners. Secondly, a review of the literature explores these research opportunities and the level of understanding to date, which results in research objectives. The third phase is the development of research design, which is discussed in this section. Fourthly and the final step is to execute the research design.

The questions in the survey questionnaire were adapted from the list of factors identified in the literature review from some researchers, such as Psomas\& Antony(2017), Sofiyabadi \& Firoozabadi, (2017); Sirvanci (2004); Becket (2008);Ardi et.al. (2012); Lagrosen et.al (2004). Then the result were combined with the quality standards published by the accreditation body of Ministry of Education (BAN-PT). In total, there were 46 factors included in the questionnaire form that represents elements of quality management exclusively in the education sector. The combination of the factors are shown in the Table1.

A five-point Likert scale ranging from very important to very unimportant was used to measure the respondents' expectations or expression of their perceived experience on various quality indicators of higher education. Lastly, respondents were asked to give comments for each section of the survey questionnaire.

This questionnaire was tested in pilot survey to a limited number of participants, before full data collection process was applied. The use of a small sample of the sample population in a pilot survey is called respondents-driven pretests and recommended (Ruel,Wagner,\& Gillespie, 2016). They fit the profile and characteristic of the larger sample who will surveyed later. This allows any modification of ambiguous questions which are difficult to understand. Pretesting the survey also helped the researcher to show that the questions appeared to be worded appropriately and clearly. This step is very important as it helps to erase any research bias, and any misunderstandings.

Furthermore, one question in the survey was made using a reverse-word technique. A reverse word question will avoid the respondents filled up the survey carelessly. Therefore, the quality of the data collected will be increased.

A dedicated website for online survey was developed for this study. An online survey gives advantage in terms of speed and enables the researcher to contact respondents to participate in the survey again to complete the questionnaire. The survey was carried out from February to April 2015 to 1,461 respondents and conducted in collaboration with the administrative staff of the university.

The survey was distributed in the end of the semester-holiday, before the students start the new semester by using the official university emails. The use of the official university emails will avoid illegal or irrelevant respondents, because only students registered in the particular university can respond to this survey.

The first stage of data analysis was descriptive statistics to explain the profile of research respondents and the general attitude of the respondents towards quality in higher education. The second part of the analysis is factor analysis to simplify the 46 factors into common components. The reliability of these analyses was evaluated through the calculation of the Cronbach's alpha coefficients.

This study has limit scope because the data conducted only from students in one particular university. Future research may be still needed to further explore the topics or generalise the findings. However, the result in this study can be applied as a references for more general higher education. 
Tabel 1. List of Factors Identified in The Previous Study

\begin{tabular}{|c|c|c|c|c|c|c|c|}
\hline & $\begin{array}{c}\text { Psomas } \\
\text { \& } \\
\text { Antony } \\
(2017) \\
\end{array}$ & $\begin{array}{c}\text { Sofiyabadi } \\
\& \\
\text { Firoozabadi } \\
(2017) \\
\end{array}$ & $\begin{array}{l}\text { Sirvanci } \\
\text { (2004) }\end{array}$ & $\begin{array}{l}\text { Becket } \\
\text { (2008) }\end{array}$ & $\begin{array}{c}\text { Ardi } \\
\text { et.al. } \\
\text { (2012) }\end{array}$ & $\begin{array}{c}\text { Lagrosen } \\
\text { et.al. } \\
(2004)\end{array}$ & BAN-PT \\
\hline Quality Culture & & $\mathrm{X}$ & $X$ & $X$ & & $\mathrm{X}$ & \\
\hline Competitive Quality & $\mathrm{X}$ & $\mathrm{X}$ & & & & $X$ & $\mathrm{X}$ \\
\hline $\begin{array}{l}\text { Quality Management } \\
\text { Sensitivity }\end{array}$ & $\mathrm{X}$ & & $\mathrm{X}$ & $\mathrm{X}$ & $\mathrm{X}$ & $\mathrm{X}$ & $\mathrm{X}$ \\
\hline Quality Communication & $\mathrm{X}$ & $\mathrm{X}$ & $\mathrm{X}$ & & $\mathrm{X}$ & $\mathrm{X}$ & $\mathrm{X}$ \\
\hline Ability in Analytical & & & & & & $\mathrm{X}$ & $\mathrm{X}$ \\
\hline Ability in Presentation & & & & & & & $\mathrm{X}$ \\
\hline Ability in IT & & & $\mathrm{X}$ & & $\mathrm{X}$ & $\mathrm{X}$ & $\mathrm{X}$ \\
\hline Ability to Work Together & $X$ & $X$ & $\mathrm{X}$ & & $\mathrm{X}$ & $\mathrm{X}$ & \\
\hline Ability in Disciplinary & $\mathrm{X}$ & & & & & & $X$ \\
\hline Timely Library References & & & $X$ & & $X$ & $X$ & $\mathrm{X}$ \\
\hline Choose Specialization & & & $\mathrm{X}$ & $X$ & & $\mathrm{X}$ & $\mathrm{X}$ \\
\hline Increasing Creativity & & $X$ & $\mathrm{X}$ & $X$ & $X$ & $\mathrm{X}$ & $\mathrm{X}$ \\
\hline Comfortable Environment & & $X$ & $\mathrm{X}$ & & $\mathrm{X}$ & $\mathrm{X}$ & $\mathrm{X}$ \\
\hline Audio Visual & & & $\mathrm{X}$ & & $\mathrm{X}$ & $X$ & $\mathrm{X}$ \\
\hline Teaching Preparation & $X$ & $X$ & $\mathrm{X}$ & $X$ & $\mathrm{X}$ & $X$ & $\mathrm{X}$ \\
\hline Syllabus Learning & $\mathrm{X}$ & $\mathrm{X}$ & $\mathrm{X}$ & $\mathrm{X}$ & $\mathrm{X}$ & $\mathrm{X}$ & $\mathrm{X}$ \\
\hline Active Participation & $\mathrm{X}$ & $\mathrm{X}$ & $\mathrm{X}$ & & & $\mathrm{X}$ & $\mathrm{X}$ \\
\hline Respect and Fair & & & & & & & $\mathrm{X}$ \\
\hline Achieving Motivation & $X$ & & & $\mathrm{X}$ & $\mathrm{X}$ & & \\
\hline Clear Explanation & $\mathrm{X}$ & $\mathrm{X}$ & & & $\mathrm{X}$ & $\mathrm{X}$ & \\
\hline Academic Activities Variation & & $\mathrm{X}$ & $\mathrm{X}$ & $\mathrm{X}$ & $\mathrm{X}$ & $\mathrm{X}$ & $\mathrm{X}$ \\
\hline Gathering Place & & & $\mathrm{X}$ & & $\mathrm{X}$ & $X$ & \\
\hline Computer Lab Access & & $\mathrm{X}$ & $\mathrm{X}$ & & $\mathrm{X}$ & $\mathrm{X}$ & $\mathrm{X}$ \\
\hline Consultation Service & & $X$ & & & $\mathrm{X}$ & $\mathrm{X}$ & \\
\hline Consultation Schedule & & & & & $\mathrm{X}$ & $\mathrm{X}$ & \\
\hline Consultation Care & & $\mathrm{X}$ & & & $\mathrm{X}$ & $\mathrm{X}$ & \\
\hline Consultation result & & & & & $\mathrm{X}$ & $\mathrm{X}$ & \\
\hline Counseling Result & & & & & & $\mathrm{X}$ & $\mathrm{X}$ \\
\hline Extracurricular Management & & & $\mathrm{X}$ & $\mathrm{X}$ & & $\mathrm{X}$ & $\mathrm{X}$ \\
\hline Extracurricular Student Club & & & $\mathrm{X}$ & $\mathrm{X}$ & & $\mathrm{X}$ & $\mathrm{X}$ \\
\hline Extracurricular Result & & & & $\mathrm{X}$ & & & $\mathrm{X}$ \\
\hline Soft Skill Service & & $\mathrm{X}$ & & $\mathrm{X}$ & & $\mathrm{X}$ & $\mathrm{X}$ \\
\hline Soft Skill in Work & & $\mathrm{X}$ & & $\mathrm{X}$ & & $X$ & $\mathrm{X}$ \\
\hline Soft Skill in Study & & $\mathrm{X}$ & & $\mathrm{X}$ & & $\mathrm{X}$ & $\mathrm{X}$ \\
\hline Scholarship Availability & & & & & & $\mathrm{X}$ & $\mathrm{X}$ \\
\hline Scholarship System & & & & & & $\mathrm{X}$ & $\mathrm{X}$ \\
\hline Scholarship Control & & & & & & $\mathrm{X}$ & $\mathrm{X}$ \\
\hline First Aid Availability & & & & & $\mathrm{X}$ & & $\mathrm{X}$ \\
\hline First Aid Facility & $\mathrm{X}$ & $\mathrm{X}$ & $\mathrm{X}$ & & $\mathrm{X}$ & $\mathrm{X}$ & $\mathrm{X}$ \\
\hline Emergency Service & $\mathrm{X}$ & & & & & & $\mathrm{X}$ \\
\hline Insurance Availability & & & & & & $\mathrm{X}$ & $\mathrm{X}$ \\
\hline Security Service & & $\mathrm{X}$ & $\mathrm{X}$ & $\mathrm{X}$ & $\mathrm{X}$ & & $\mathrm{X}$ \\
\hline Cleaning Service & & & $\mathrm{X}$ & $\mathrm{X}$ & $\mathrm{X}$ & & $\mathrm{X}$ \\
\hline Food Court & & & $\mathrm{X}$ & & $\mathrm{X}$ & $X$ & \\
\hline Parking Lot Service & & & $\mathrm{X}$ & $\mathrm{X}$ & $\mathrm{X}$ & $\mathrm{X}$ & $\mathrm{X}$ \\
\hline Book Store & & & $\mathrm{X}$ & & & $X$ & \\
\hline
\end{tabular}




\section{RESULT AND DISCUSSION}

This section is divided into two parts, there are result and discussion. Those sections are explained below.

\section{Result}

A reasonable number of collected data has been compiled into Microsoft Excel and SPSS data files. The researcher used SPSS program to analyze the data into useful information, suggesting conclusion and managerial implications. SPSS is an advanced statistical analysis program suitable to a wide variety of descriptive and inferential statistical techniques such as factor analysis and is highly extensible.

The profiles of the respondents are summarized in Table 2. A total of 1,461 respondents have been collected, consisting of active students of the undergraduate program from the four programs; Accounting, Business, Finance, and Marketing. The number of students is approximately $72 \%$ of the total student body. Most respondents $(66.05 \%)$ come from the Business program, followed by $17.59 \%$ students of the Marketing program, $8.49 \%$ students of the Accounting program, and $7.87 \%$ students of the Finance program.

Tabel 2. Program Composition of Respondents

\begin{tabular}{lcc}
\hline \multicolumn{1}{c}{ Program } & Frequency & Percent \\
\hline Accounting & 124 & 8.49 \\
Business & 965 & 66.05 \\
Finance & 115 & 7.87 \\
Marketing & 257 & 17.59 \\
\hline Total & $\mathbf{1 , 4 6 1}$ & $\mathbf{1 0 0}$ \\
\hline
\end{tabular}

To evaluate the different dimensions of education quality, a factor analysis was conducted using SPSS. In this research, there were 46 variables used in the analysis which derived from variables found in the previous research. The objective of the factor analysis is to reduce the number of variables into a smaller number of components which are easier to understand and interpreted (Field, 2009). The 46 Variables are listed in Table 3.

Tabel 3. Variables of Quality in Higher Education

\begin{tabular}{clcclc}
\hline No & \multicolumn{1}{c}{ Name } & Code & No & Name & Code \\
\hline 1 & Quality Culture & X1 & 24 & Consultation Service & X24 \\
2 & Competitive Quality & $\mathbf{X 2}$ & 25 & Consultation Schedule & $\mathbf{X 2 5}$ \\
3 & Quality Management Sensitivity & $\mathbf{X 3}$ & 26 & Consultation Care & $\mathbf{X 2 6}$ \\
4 & Quality Communication & $\mathbf{X 4}$ & 27 & Consultation Result & $\mathbf{X 2 7}$ \\
5 & Ability in Analytical & $\mathbf{X 5}$ & 28 & Counseling Result & $\mathbf{X 2 8}$ \\
6 & Ability in Presentation & $\mathbf{X 6}$ & 29 & Extracurricular Management & $\mathbf{X 2 9}$ \\
7 & Ability in IT & $\mathbf{X 7}$ & 30 & Extracurricular Student Club & $\mathbf{X 3 0}$ \\
8 & Ability to Work Together & $\mathbf{X 8}$ & 31 & Extracurricular Result & $\mathbf{X 3 1}$ \\
9 & Ability in Disciplinary & $\mathbf{X 9}$ & 32 & Soft Skill Service & $\mathbf{X 3 2}$ \\
10 & Timely Library References & $\mathbf{X 1 0}$ & 33 & Soft Skill in Work & $\mathbf{X 3 3}$ \\
11 & Choose Specialization & $\mathbf{X 1 1}$ & 34 & Soft Skill in Study & $\mathbf{X 3 4}$ \\
12 & Decreasing Creativity & $\mathbf{X 1 2}$ & 35 & Scholarship Availability & $\mathbf{X 3 5}$ \\
13 & Comfortable Environment & $\mathbf{X 1 3}$ & 36 & Scholarship System & $\mathbf{X 3 6}$ \\
14 & Audio Visual & $\mathbf{X 1 4}$ & 37 & Scholarship Control & $\mathbf{X 3 7}$ \\
15 & Teaching Preparation & $\mathbf{X 1 5}$ & 38 & First Aid Availability & $\mathbf{X 3 8}$ \\
16 & Syllabis Teaching & $\mathbf{X 1 6}$ & 39 & First Aid Facility & $\mathbf{X 3 9}$ \\
17 & Active Participation & $\mathbf{X 1 7}$ & 40 & Emergency Service & $\mathbf{X 4 0}$ \\
18 & Respect and Fair & $\mathbf{X 1 8}$ & 41 & Insurance Availability & $\mathbf{X 4 1}$ \\
19 & Achieving Motivation & $\mathbf{X 1 9}$ & 42 & Security Service & $\mathbf{X 4 2}$ \\
20 & Clear Explanation & $\mathbf{X 2 0}$ & 43 & Cleaning Service & $\mathbf{X 4 3}$ \\
21 & Academic Activities Variation & $\mathbf{X 2 1}$ & 44 & Food Court & $\mathbf{X 4 4}$ \\
22 & Gathering Place & $\mathbf{X 2 2}$ & 45 & Parking Lot Service & $\mathbf{X 4 5}$ \\
23 & Gathering Lab Access & $\mathbf{X 2 3}$ & 46 & Book Store & $\mathbf{X 4 6}$ \\
\hline
\end{tabular}


Before the factor analysis was performed, various assumptions on the inter-correlations of the 46 variables were tested. Dehqan, Yadegari, Scherer, Asgari, \& Dabirmoghadam (2017) suggest the determinant of correlation matrix has to be very small, or closer to 0 . If the determinant value is closer to 0 , it means that each variable involved is interrelated, which is important in a factor analysis. The output of SPSS calculation shows that the determinant value is close to 0 . The Bartlett's test value is also very small $(\mathrm{P}<.001)$ and thereby shows suitability of the data for factor analysis. The Kaiser-Meyer-Olkin (KMO) measurement of sampling adequacy for the 46 variables equals to .972 . As discussed by Field (2009), .5 is the minimum value of KMO and the worldwide accepted index is $>.6$ (Dehqan et al., 2017) to be used for factor analysis. Thus, our data show that it can be used for factor analysis. One variable (X12) has an extraction value (communalities value) of .489 and we have to omit this variable. Field (2009) suggests communalities value must be higher than .5 each variable. Therefore, the communality assumption has only been fulfilled for 45 variables.

Because all assumptions have been fulfilled, the next step is to identify the number of components from the 45 variables. Table 4 below shows the number of components identified from all variables. We choose components where the Eigenvalues are more than 1. There are seven components that have the Eigenvalue $>1$ as shown in Table 3. The variance that can be explained by these seven components includes $48.251 \%+6.053 \%+3.758 \%+3.410 \%+$ $2.704 \%+2.376 \%+2.250 \%=68.801 \%$.

Tabel 4. Number of Components Identified From All Variables

\begin{tabular}{crrr}
\hline \multicolumn{3}{c}{ Total Variance Explained } \\
\hline \multirow{3}{*}{ Component } & \multicolumn{3}{c}{ Initial Eigenvalues } \\
\cline { 2 - 4 } & Total & \% of Var & $\begin{array}{c}\text { Cumulative } \\
\text { \% }\end{array}$ \\
\hline 1 & 21.713 & 48.251 & 48.251 \\
2 & 2.724 & 6.053 & 54.304 \\
3 & 1.691 & 3.758 & 58.062 \\
4 & 1.535 & 3.410 & 61.472 \\
5 & 1.217 & 2.704 & 64.176 \\
6 & 1.069 & 2.376 & 66.552 \\
7 & 1.012 & 2.250 & 68.801 \\
\hline
\end{tabular}

We also use the scree plot (see Figure 1) to identify the number of components. The cutoff point for selecting factors should be at component number 7 which is the point of inflection of this curve. This confirms our findings in Table 3.

Scree Plot

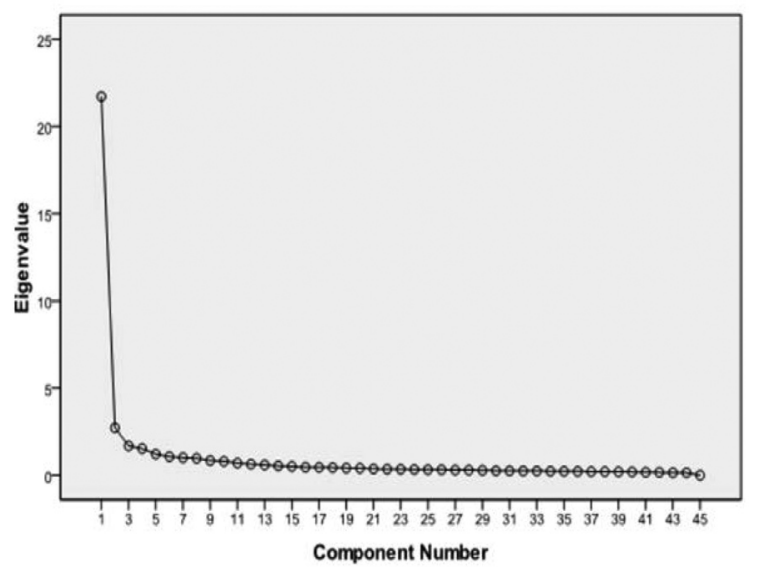

Figure 1. Scree Plot of 46 Variables

SPSS then was used to calculate the rotated component matrix that is used to group the 45 variables into 7 components. Each variable has a large loading factor value (above .4). Field (2009) recommends a minimum value .4 for an identified factor loading to be considered as statistically meaningful. A study by MacCallum, Widaman, Zhang, \& Hong (1999) suggests that the result of factor analysis is fairly accurate if the sample size is larger than 500. A large sample size helps to eliminate low communalities and over-determination of components. The samples collected in this study were 1,461 data which were more than enough to fulfill the high validity and reliability criteria. The large sample size is also helpful to avoid weak components, especially when the numbers of components are large in the output of factor analysis.

Dehqan et. al, (2017) suggest that after the implementation of factor analysis and distinctive cluster definitions, the internal consistency determination of a set of items indicating the distinctive factor is essential. A conventional method for estimating the internal consistency is by calculating Cronbach's alpha coefficient for each component. Table 5 presents the results of the calculation of the 7 identified components $(\mathrm{C} 1-\mathrm{C} 7)$ in this study. 
Tabel 5. Cronbach's Alpha Value

\begin{tabular}{ccc}
\hline Components & $\begin{array}{c}\text { Cronbach's } \\
\text { Alpha }\end{array}$ & N of Items \\
\hline C1 & .930 & 11 \\
C2 & .936 & 5 \\
C3 & .916 & 7 \\
C4 & .922 & 4 \\
C5 & .904 & 6 \\
C6 & .832 & 4 \\
C7 & .896 & 3 \\
\hline
\end{tabular}

Generally, an internal consistency of á e". 90 is considered excellent and .70 d"á $<.90$ is considered good. As shown in Table 5 the Cronbach's Alpha coefficients were high for the extracted factors. This implies that the number of factors was accurately derived.

The summary of the seven components can be seen in Table 6 . These seven components explain $68.801 \%$ of the variance. Variables in each component interpretation show important factors in determining the quality of higher education.

Tabel 6. Summary of 7 Components

\begin{tabular}{cl}
\hline Components & \multicolumn{1}{c}{ Variables } \\
\hline $\mathrm{C} 1$ & $\mathrm{X} 1, \mathrm{X} 2, \mathrm{X} 3, \mathrm{X} 4, \mathrm{X} 5, \mathrm{X} 6, \mathrm{X} 7, \mathrm{X} 8$, \\
& $\mathrm{X} 9, \mathrm{X} 10, \mathrm{X} 11$ \\
$\mathrm{C} 2$ & $\mathrm{X} 24, \mathrm{X} 25, \mathrm{X} 26, \mathrm{X} 27, \mathrm{X} 28$ \\
$\mathrm{C} 3$ & $\mathrm{X} 35, \mathrm{X} 36, \mathrm{X} 37, \mathrm{X} 38, \mathrm{X} 39, \mathrm{X} 40$, \\
& $\mathrm{X} 41$ \\
$\mathrm{C} 4$ & $\mathrm{X} 21, \mathrm{X} 22, \mathrm{X} 23, \mathrm{X} 29, \mathrm{X} 30, \mathrm{X} 31$, \\
& $\mathrm{X} 32, \mathrm{X} 33, \mathrm{X} 34$ \\
$\mathrm{C} 5$ & $\mathrm{X} 15, \mathrm{X} 16, \mathrm{X} 17, \mathrm{X} 18, \mathrm{X} 19, \mathrm{X} 20$ \\
$\mathrm{C} 6$ & X13, X14, X42, X43 \\
$\mathrm{C} 7$ & $\mathrm{X} 44, \mathrm{X} 45, \mathrm{X} 46$ \\
\hline
\end{tabular}

The detail of the seven components can generally be interpreted as follows. The first component $(\mathrm{C} 1)$ which consists of eleven variables can beinterpreted as Quality Component of Explicit Demonstration for Quality in terms of Management and Students Ability. It means that higher education institutions must pay extra attention to cultivating culture to increase the quality and the capability to of students' overall ability.

The second component $(\mathrm{C} 2)$ consisting of five variables can be interpreted as Quality Component of Counseling Service. It means that higher education institutions have to be able to provide excellent counseling service aiming to help students to overcome their academic and personal problems and also to increase their optimism and confidence.

The third component (C3) consists of seven variables emphasize the urgency of health care facility, that can be interpreted as Quality Component of Healthcare and Insurance. This component finding in this research suggests that higher education institutions complete their healthcare service with ambulance availability, nearest hospital contacts, and in-house healthcare personnel such as nurses or doctors.

The fourth component $(\mathrm{C} 4)$ consists of nine variables which can be interpreted as Variety of Supporting Student Activities. Higher education institutions are is strongly suggested to have a wide variety of non-academic extracurricular activities which supports the development of student's talents in accordance with their interest.

The fifth component (C5) consists of six variables, interpreted as Excellent Teachers Quality in which teachers deliver quality learning experience.

The sixth component (C6) consists of four variables, interpreted as Good Ambiance Campus Environment. It means that higher education institutions must maintain the hygiene of school's environment, good security service such as providing lost and found service, creating good ambience around the school through music, and overall a comfortable environment to support students' learning motivation.

The seventh component (C7) consists of three variables which can be interpreted as Campus Physical Facilities. A sufficient number of parking lots, maintaining its security, a clean food court with various food choices, and a bookstore must be provided by higher education institutions.

\section{Discussion}

The previous section has identified seven components that the have impacts on the quality management system in higher education. These components must be well-understood by university, college, schools and other higher education institution management to achieve better quality in higher education.

The first component $(\mathrm{C} 1)$ can be attained by providing an up-to-date textbook and orientation program. Management of the school must be 
able to facilitate demonstration of this quality by all stakeholders, especially students in everyday campus activities. For example, business students must wear formal clothes in the campus area to show the culture of professionalism, punctual class schedule in which no tardiness is allowed shows discipline, and active lecture or class discussion shows students' analytical ability. Those cultures and abilities become the desired quality characteristics shown by students in higher education institution.

The study by Setiyowati, Pali, Wiyono, \&Triyono(2019) identifies basic attitude as the most important factor to the counseling competency. Basic attitude consists of genuine, unconditional positive regard, empathic understanding, and trust. Our research support this finding, in terms of the second component (C2). It can be demonstrated by the availability of counselors with genuine care when students admit to being bullied by other students, or facing abuse at home. Students' mental health has attracted many attentions as one the factor that affects a decrease in academic performance and other students' comfort in campus environment (Prince, 2015). Therefore, counselors should present themselves 24 hours ready to be contacted when students are facing those difficulties. This finding is supported by Obi (2015) who found that an adequate amount of career counseling provided by school for undergraduate students reduces anxiety, uncertainty, insecurity and indecision about their future goal.

The third component $(\mathrm{C} 3)$ means that healthcare and insurance availability is a common norm in higher education institutions and also becomes a major key factor that must cover every stakeholder. The previous study fails to mention this component especially the importance of insurance.

The fourth component (C4) means that higher education institutions must provide enough high quality soft skill programs. For example: seminars, workshops and extracurricular activities. Most universities in Indonesia provide extracurricular sport activities (basketball, soccer, ping-pong, etc.) and religionrelated extracurricular activities for each religion such as Christian, Islam, Buddha, and Hindu. A study by Tari \& Dick (2016) found similarity in terms of the importance of people management such as training and professional development.
The fifth component (C5) should be demonstrated in terms of well-prepared teaching materials, ability to encourage active learning and give motivation to students to achieve excellent accomplishments. Recent study by Gunawan, Sahidu, Harjono, \&Suranti(2017) found that involving students actively in classincreased students' creativity and produced higher average score than a conventional class. The result of this study is also supported by studies by Basari, Altinay, Dagli, \&Altinay (2016) and Psomas \& Antony (2017) that highlight qualified academic staff as one of most important factors. Tari \& Dick (2016) also support this finding, i.e. designing the learning process determines the process management quality.

The sixth component (C6) is rarely discussed in the previous studies. Here, the school should create a conducive and cozy environment for students and faculty members. First, adding music in the study room as suggested by Matney (2017) in his research shows a significant decrease in anxiety among university students in facing stressful class assignments. Second, regular cleanliness checking schedule, building trust to security personnel and quality inspection of school's facility must be carried out. A previous study by Simangunsong (2014) found empirical data that $24 \%$ undergraduate students are unconventional learners. This means different teaching techniques and unconventional campus environment might be preferred by most students.

The seventh component (C7) is represented by the School's ability to provide enough parking lots, maintaining its security, providing a clean food court with various food choices, and a bookstore. This finding is also supported by El Asmar, Chokor, \& Srout (2014) who found that the improvement of Indoor Environmental Quality (IEQ) can lower absenteeism and escalate stakeholders' performance. Grant et. al (2004) found that campus physical facilities are very important in determining quality-of-design to get stakeholder's satisfaction. Although not the most important factor to student satisfaction, the study by Kardoyo\&Nurkhin(2016) also mentions the necessity of University management to pay attention to campus cleanliness, sanitation, parking, and other supporting facilities.

These seven components are quality demanded by stakeholders, especially students, 
beyond the existing accreditation standards. Through an explicit demonstration for quality by stakeholders, healthcare and insurance, and good ambience campus environment become major new findings in this study. Therefore, these components must be considered by school and university management in shaping the culture that is strongly demonstrated by all stakeholders, as well as creating a quality control system to enhance each variable's implementation in order to deliver high quality higher education institutions.

\section{CONCLUSION}

Quality Management in higher education has developed to a degree where it is viewed as a foundation for competition. However, there is still no agreement on the best method to measure and manage quality in higher education. Most higher educations, especially business schools, use accreditation (EQUIS, AACSB, AMBA, National Accreditation) to showcase quality performance, although, as discussed in this study, many researches argue that accreditation and school ranking are not directly linked with actual quality management implementation.

A factor analysis is conducted to select and group 46 quality variables into components that really matter to stakeholders, especially students. After analyzing the 46 variables, this study results in seven components. These seven identified components have strong managerial implications. Some of the findings are new, i.e., the importance of providing health and insurance for stakeholders shows one of the highest scores. Another new finding is the importance of good ambiance campus environment to cater most students who are unconventional learners. The third new finding is the quality of management and students' ability which can no longer be shown by verbal or visual communication, but must also be strongly demonstrated by stakeholders to determine a quality in higher education. Those findings have rarely been discussed in the previous studies.

Managing quality in higher education is a definitely demanding task. The result of this study should help higher education institutions to develop a working quality management system that goes beyond quality standards, which is usually used for accreditation purposes only. The empirical findings in this study can also be used as reference for higher education institutions to compare their quality dimensions in other countries and Indonesia.

\section{REFERENCES}

Ardi, R., Hidayatno, A., \&Zagloel, Y. M. (2012). Investigating relationships among quality dimensions in higher education. Quality Assurance in Education, 20(4), 408-428. doi:10.1108/09684881211264028.

Barton, H., \& Yazdani, B. (2013). Managing for the future in higher education: A case study on "lean" implementation within a UK Business School.Journal of Business and Economics, 4(11), 1133-1139.

Basari, G., Altinay, Z., Dagli, G., \&Altinay, F. (2016). Assessment of the quality management models in higher education. Journal of Education and Learning, 5(3), 107-121. doi:10.5539/jel.v5n3p107.

Becket, N. (2008). Quality management practice in higher education - What quality are we actually enhancing? The Journal of Hospitality, Leisure, Sport and TourismEducation, 7(1), 40-54. doi:10.3794/johlste.71.174.

Dehqan, A., Yadegari, F., Scherer, R. C., Asgari, A., \& Dabirmoghadam, P. (2017). Iranian Voice Quality of Life Profile (IVQLP): Factor analysis. Journal of Voice,5(31), 576-582. doi:10.1016/j. jvoice.2017.01.001.

El Asmar, M., Chokor, A., \&Srout, I. (2014). Occupant satisfaction with Indoor Environmental Quality: a study of LEEDcertified buildings on the Arizona State University Campus, Amerika Society of Civil Engineers. International Conference on Sustainable Infrastructure (pp. 10631070). Long Beach, CA: American Society of Civil Engineers (ASCE). doi:10.1061/9780784478745.100.

Field,A.(2009). Discovering statistics using SPSS (3rd ed.). London: Sage publications. 
Grant, D., Mergen, E., \& Widrick, S. (2004). A comparative analysis of quality management in US and international universities. Total Quality Management \& Business Excellence, 15(4), 423-438.: doi :10.1080/1478336042000183613.

Gunawan, Sahidu, H.,Harjono, A.\& Suranti, N. M. Y. (2017). Efektivitas penerapan model project based learning berbantuan media virtual terhadap kreativitas fisika peserta didik. Jurnal Cakrawala Pendidikan, 36(2), 167-179.doi:10.21831/ cp.v36i2.13514.

Hellsten, U., \& Klefsjö, B. (2000). TQM as a management system consisting of values, techniques and tools. The TQM Magazine, 12(4), 238-244. doi:10.1108/09544780010325822.

Istileulova, Y., \& Peljhan, D. (2013). How accreditation stimulates business school change: Evidence from the commonwealth of independent states. Dynamic Relationships Management Journal,2(1), 15-29.doi: $\quad$ 10.17708/DRMJ.2013. $\mathrm{v} 02 \mathrm{n} 01 \mathrm{a} 02$.

Kardoyo\& Nurkhin, A. (2016). Analisis kepuasan pelayanan perguruan tinggi (kasus pada Prodi Magister Pendidikan Ekonomi Unnes). Jurnal Cakrawala Pendidikan,35(2), 164-175. doi:10.21831/ cp.v15i2.9881.

Lagrosen, S., Seyyed-Hashemi, R., \& Leitner, M. (2004). Examination of the dimensions of quality in higher education. Quality Assurance in Education, 12, 61-69. doi:10.1108/09684880410536431.

MacCallum, R. C., Widaman, K. F., Zhang, S., \& Hong, S. (1999). Sample size in factor analysis. Psychological Methods, 4(1), 84-99.doi: 10.1037/1082-989X.4.1.84.

Martensson, P., \& Richtner, A. (2015). What parameters do students value in business school rankings? Journal of Higher Education Policy and Management, 37(6),
646-658. doi:10.1080/1360080X.2015.1 102821.

Matney, B. (2017). The effect of specific music instrumentation on anxiety reduction in university music students: A feasibility study.The Arts in Psychotherapy, 54(February 2017), 47-55. doi:10.1016/j. aip.2017.02.006.

Mohammed, A. H., Bin Taib, C. A., \& Nadarajan, S. (2016). Infrastructure and core quality management practices in higher education performance. International Journal of Supply Chain Management, 5(2), 138143.

Nigsch, S., \& Schenker-Wicki, A. (2013). Shaping performance: do international accreditations and quality management really help? Journal of Higher Education Policy and Management, 35(6), 668-681. doi:10.1080/1360080X.2013.844669.

Nitecki, D. A., \&Hernon, P. (2000). Measuring service quality at yale university's libraries. The Journal of Academic Librarianship, 26(4), 259-273. doi:10.1016/S00991333(00)00117-8.

Obi, O. P. (2015). Constructionist career counseling of undergraduate students: An experimental evaluation. Journal of Vocational Behavior, 88(June 2015), 215219. doi:10.1016/j.jvb.2015.03.009.

Pires, A. R. (2015). Quality management system in a portuguese higher polytechnic institute: Difficulties and potentialities. In Toulon-Verona Conference, "Excellence in Services". Retrieved from http://www. toulonveronaconf.eu/papers/index.php/ tvc/article/view/321

Prince, J. P. (2015). University student counseling and mentalhealth in the United States: trends and challenges. Mental Health and Prevention, 3(1-2), 5-10. doi:10.1016/j. mhp.2015.03.001.

Psomas, E., \& Antony, J. (2017). Total quality management elements and results in 
higher education institutions: The Greek case. Quality Assurance in Education, 25(2), 206-223. doi:10.1108/QAE-082015-0033.

Ruel, E., Wagner, W. E., \& Gillespie, B. J. (2016). The practice of survey research: theory and applications. Thousand Oaks, CA:SAGE Publications, Inc. doi:10.4135/9781483391700.

Setiyowati, A. J., Pali, M., Wiyono, B. B., \& Triyono. Structural model of counseling competence. Jurnal Cakrawala Pendidikan, 38(1), 45-62. doi:10.21831/ cp.v38i1.21509.

Simangunsong, E. (2014). An empirical study of felder and silverman's ils in undergraduate program of $\mathrm{ABC}$ University to increase quality \& education processes. In Conference: 2nd Gadjah Mada International Conference on Economics and Business, (Volume 1), Yogyakarta, Indonesia.

Sirvanci, M. B. (2004). Critical issues for TQM implementation in higher education. The TQM Magazine, 16(6), 382-386. doi:10.1108/09544780410563293.

Sofiyabadi, J., \& Firoozabadi, K. J. (2017). TQM in higher education: Fuzzy ranking based on AQIP components.Palma Journal, 16, 218-226.
Srikanthan, G., \& Dalrymple, J. (2003). Developing alternative perspectives for quality in higher education. International Journal of Educational Management, $\quad$ 17(3), 126-136. doi:10.1108/09513540310467804.

Tari, J. J., \& Dick, G. (2016). Trends in quality management research in higher education institutions. Journal of Service Theory and Practice, 26(3), 273-296. doi:10.1108/ JSTP-10-2014-0230.

Teeroovengadum, V., Kamalanabhan, T. J.,\& Seebaluck, A. K. (2016). Measuring service quality in higher education: Development of a hierarchical model (HESQUAL). Quality Assurance in Education, 24(2), 244-258. doi:10.1108/ QAE-06-2014-0028.

Van Vught, F. A. \&Westerheijden, D. F. (1994). Towards a general model of quality assessment in higher education. Higher Education, 28(3), 355-371. doi:10.1007/ BF01383722.

Williams, G. (1993). Total quality management in higher education: Panacea or Placebo? Higher Education, 25(3), 229-237. doi:10.2307/3447794. 